\title{
Stratigraphic framework of the late Miocene Pisco Formation at Cerro Los Quesos (Ica Desert, Peru)
}

\author{
C. Di Celma, E. Malinverno, G. Cantalamessa, A. Gioncada, G. Bosio, I.M. Villa, \\ K. Gariboldi, A. Rustichelli, P.P. Pierantoni, W. Landini, C. Tinelli, A. Collareta \\ \& G. Bianucci
}

To cite this article: C. Di Celma, E. Malinverno, G. Cantalamessa, A. Gioncada, G. Bosio, I.M. Villa, K. Gariboldi, A. Rustichelli, P.P. Pierantoni, W. Landini, C. Tinelli, A. Collareta \& G. Bianucci (2016) Stratigraphic framework of the late Miocene Pisco Formation at Cerro Los Quesos (Ica Desert, Peru), Journal of Maps, 12:5, 1020-1028, DOI: 10.1080/17445647.2015.1115783

To link to this article: http://dx.doi.org/10.1080/17445647.2015.1115783

+ View supplementary material $₫$

Submit your article to this journal

\section{Submit your article to this journal cr}

View related articles $\sqsubset$

View Crossmark data $\nearrow$

Citing articles: 5 View citing articles 


\title{
Stratigraphic framework of the late Miocene Pisco Formation at Cerro Los Quesos (Ica Desert, Peru)
}

\author{
C. Di Celma ${ }^{a}$, E. Malinverno ${ }^{b}$, G. Cantalamessa ${ }^{a}$, A. Gioncada ${ }^{c}$, G. Bosio ${ }^{\text {b }}$, I.M. Villa ${ }^{\text {b }}$, K. Gariboldi ${ }^{\text {,d }}$, \\ A. Rustichelli ${ }^{a}$, P.P. Pierantoni ${ }^{a}$, W. Landini ${ }^{c}$, C. Tinelli ${ }^{c}$, A. Collareta ${ }^{c, d}$ and G. Bianucci ${ }^{c}$
}

${ }^{\mathrm{a} S}$ Scuola di Scienze e Tecnologie, Università di Camerino, Camerino, Italy; ${ }^{\mathrm{b}}$ Dipartimento di Scienze dell'Ambiente e del Territorio e di Scienze

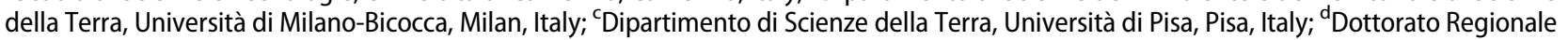
in Scienze della Terra Pegaso, Pisa, Italy

The enormous concentration of marine vertebrates documented within the Pisco Formation is unique for Peru and South America and places this unit among the prime fossil Lagerstätten for Miocene to Pliocene marine mammals worldwide. In order to provide a robust stratigraphic framework for the fossil-bearing locality of Cerro Los Quesos, this study presents a 1:10,000 scale geological map covering an area of about $21 \mathrm{~km}^{2}$, a detailed measured section spanning $290 \mathrm{~m}$ of strata, and a refined chronostratigraphy for the studied succession well constrained by diatom biostratigraphy and high-resolution ${ }^{40} \mathrm{Ar} /{ }^{39} \mathrm{Ar}$ isotopic dating of three interbedded ash layers. Within the apparently monotonous, diatomite-dominated sedimentary section, the Pisco Formation has been subdivided into six local members, with stratigraphic control over the different outcrops facilitated by the establishment of a detailed marker bed stratigraphy based on 15 readily distinguishable sediment layers of different nature.
ARTICLE HISTORY

Received 4 July 2015

Revised 28 October 2015

Accepted 30 October 2015

KEYWORDS

Pisco formation; late

Miocene; Cerro Los Quesos;

stratigraphy; diatom

biostratigraphy; ${ }^{40} \mathrm{Ar} /{ }^{39} \mathrm{Ar}$

isotopic dating

\section{Introduction}

The Miocene to Pliocene Pisco Formation, southern Peru, is world renowned for the extraordinary preservation and unusual abundance of marine vertebrates, which have been extensively studied for their systematic and taphonomic implications (e.g. Bianucci, Lambert, \& Post, 2010; Brand, Esperante, Chadwick, Poma Porras, \& Alomía, 2004; Ehret et al., 2012; Esperante, Brand, Chadwick, \& Poma, 2015; Esperante, Brand, Nick, Poma, \& Urbina, 2008; Gariboldi et al., 2015; Lambert, Bianucci, \& de Muizon, 2008; Lambert, Bianucci, \& Post, 2009, 2010; Lambert, Bianucci, Post, de Muizon, et al., 2010; Lambert, Bianucci, \& Beatty, 2014; Lambert, de Muizon, \& Bianucci, 2014; Lambert et al., 2015; Collareta et al., 2015). However, despite the growing significance of the vertebrate fauna of the Pisco Formation, a comprehensive stratigraphic framework for individual fossil-bearing localities and their position relative to one another has yet to be established (Brand, Urbina, Chadwick, DeVries, \& Esperante, 2011; Di Celma et al., in press). In order to develop a robust basin-wide stratigraphic framework allowing for comparisons among the various fossiliferous localities and to provide refined stratigraphic frameworks and age constraints for some of the historic fossil-bearing sites, over the last two years new stratigraphic analyses of the Pisco Formation have been performed in parallel with intensive paleontological prospecting within the Ica Desert (Bianucci, Di Celma, Collareta, et al., in press; Bianucci, Di Celma, Landini, et al., in press).

This paper documents the stratigraphic and structural architecture of the Pisco Formation at Cerro Los Quesos, one of the most representative fossilbearing localities in the Ica Desert, and its main objectives are: (i) to use exceptionally well-exposed outcrops to compile a complete, high-resolution stratigraphic section for the Pisco Formation at this site; (ii) to map the discrete stratigraphic intervals and marker beds it contains; and (iii) to refer them to a robust, high-resolution chronostratigraphic framework resulting from diatom biostratigraphy and high-resolution ${ }^{40} \mathrm{Ar} /{ }^{39} \mathrm{Ar}$ isotopic dating of volcanic ash layers.

\section{Geological setting}

The Tertiary collision between the Nazca Plate and South American Plate (e.g. Barazangi \& Isacks, 1979; Cahill \& Isacks, 1992; Pilger, 1981) deformed the leading edge of the South American Plate and developed a composite transform-convergent margin characterized by normal and strike-slip faults that formed extensional and pull-apart basins along the western margin of Peru (e.g. León, Aleman, Torres, Rosell, \& De La Cruz, 2008; Zúñiga-Rivero, Klein, Hay-Roe, \& Álvarez-Calderon, 2010). According to Thornburg and Kulm (1981), two trench-parallel structural ridges 
were formed on the continental shelf and upper slope during Late Cretaceous-early Paleogene time, namely the Outer Shelf Ridge and the Upper Slope Ridge. These two ridges subdivided the Peruvian offshore into a series of sedimentary basins (Figure 1), which may be separated into an inner set of shelf basins and a seaward set of slope basins. The (East) Pisco Basin, in southern Peru, is the onshore sector of one of these basins. It is a $180 \times 30 \mathrm{~km}$ elongated sedimentary basin bounded to the east by Mesozoic igneous rocks of the Coastal Batholith (Cobbing, 1999; Mukasa, 1986) and to the west by Precambrian to Jurassic metamorphic, igneous, and sedimentary rocks of the Coastal Cordillera, the onshore segment of the offshore Outer Shelf Ridge (Romero, Valencia, Alarcón, Peña, \& Ramos, 2013 and references therein). The basin fill comprises, from the oldest to the youngest, the Eocene Caballas Formation and Paracas Group, the late Oligocene-middle Miocene Chilcatay Formation, and the middle Miocene-Pliocene Pisco Formation (DeVries, 1998; Dunbar, Marty, \& Baker, 1990). These units are bounded by regionally extensive angular unconformities commonly demarcated by pavements of igneous pebble to boulder clasts and recording periods of subaerial exposure (Figure 2).

Rapid uplift and inversion of the basin, starting since the late Pliocene, is thought to be related to the oblique subduction of the aseismic Nazca Ridge, an area of topographically high, buoyant oceanic crust that is presently being subducted beneath the South American Plate adjacent to the Pisco Basin (Hampel, 2002; Hsu, 1992; Macharé \& Ortlieb, 1992; Pilger, 1981).

\section{Study area and methods}

The study area is located at Cerro Los Quesos, some 50 $\mathrm{km}$ south of the Ica town, and covers a surface of approximately $21 \mathrm{~km}^{2}$. Physical stratigraphy and architecture of the Pisco Formation strata exposed in this area were documented through conventional geological field methods, including bed-by-bed sedimentological logging, geological mapping at 1:10,000 scale (Main Map), and field-based structural characterization integrated with the analysis of high-resolution Google Earth imagery to document all the faults that must be identified in order to accurately reconstruct the section. The minimum vertical displacement of mapped faults is $3 \mathrm{~m}$.

A stratigraphically complete, composite column was assembled by combining four individual measured sections that were laterally correlated in the field by walking out several local marker beds across the many faults that crisscross the area. These sections were created by measuring the stratigraphy at 1:50 scale (minimum resolvable bed thickness about $5 \mathrm{~cm}$ ) with a Jacob's staff and describing the lithology in the field. For every single bed, grain size, thickness, color, composition, texture, sedimentary structures, amount and type of bioturbation, and macrofossil contents were documented.

A total of 87 bulk samples for diatom biostratigraphic analysis (about $1-3 \mathrm{~cm}^{3}$ each) were collected at about $4 \mathrm{~m}$ intervals. Once prepared, samples were observed by means of a Leitz Diaplan light microscope at $630 \mathrm{x}$ and $1000 \mathrm{x}$ magnification.

All the 59 distal fallout ash beds documented in the stratigraphic profile of Cerro Los Quesos were sampled and inspected under a stereomicroscope for identification of the main juvenile and lithic components; a selection was analyzed for their grain size, mineral assemblage, and chemical characters. Some of the samples were collected from different parts (i.e. finer and coarser) of individual ash layers but most of them were bulk samples. For this study, biotite from three distinct ash layers was selected for ${ }^{40} \mathrm{Ar} /{ }^{39} \mathrm{Ar}$ dating by step-heating. The ${ }^{40} \mathrm{Ar} /{ }^{39} \mathrm{Ar}$ analyses were made using a multicollector noble gas mass spectrometer (NuInstruments ${ }^{\mathrm{TM}}$ Noblesse) at Centro Universitario Datazioni e Archeometria, Università di MilanoBicocca, Milan, Italy, following procedures given by Villa, Hermann, Müntener, and Trommsdorff (2000).

\section{Physical stratigraphy and structural framework}

\subsection{Stratigraphic succession}

The stratigraphy of the study area consists of sandstone, siltstone, and tuffaceous and diatomaceous mudstone sedimentary rocks forming a gently eastdipping, layer-cake succession that is disrupted by small-displacement normal faults. Dip angles are between $5^{\circ}$ and $6^{\circ}$ in the western part of the area, lessening to $3^{\circ}-4^{\circ}$ at the eastern end.

Four measured stratigraphic sections were tied together to construct a complete, 290 m-thick composite section (Figure 3 ) displaying an overall absence of lithostratigraphic evidence for emergence and major time gaps. Six informal members, designated by the letters $\mathrm{A}$ through $\mathrm{F}$ in ascending order, have been defined based on their stratigraphic position, lithofacies associations, and correlation through detailed geologic mapping.

In order to avoid problems with correlations between different exposures and across areas of intense faulting and in an attempt to further refine the six intervals identified above, lateral tracing of 15 closely spaced marker horizons has been necessary. These marker beds, which allow quick determination of the stratigraphic position of an outcrop in the field, were informally named (in ascending order) Alcatraz, Araña, Árbol, Ballena, Colibrí, Cóndor, Espiral, Estrella, Flor, Lagarto, Manos, Mono, Pájaro, Pelícano, and Perro after the geoglyphs found in the Nazca desert. Most of these marker beds are similar in 


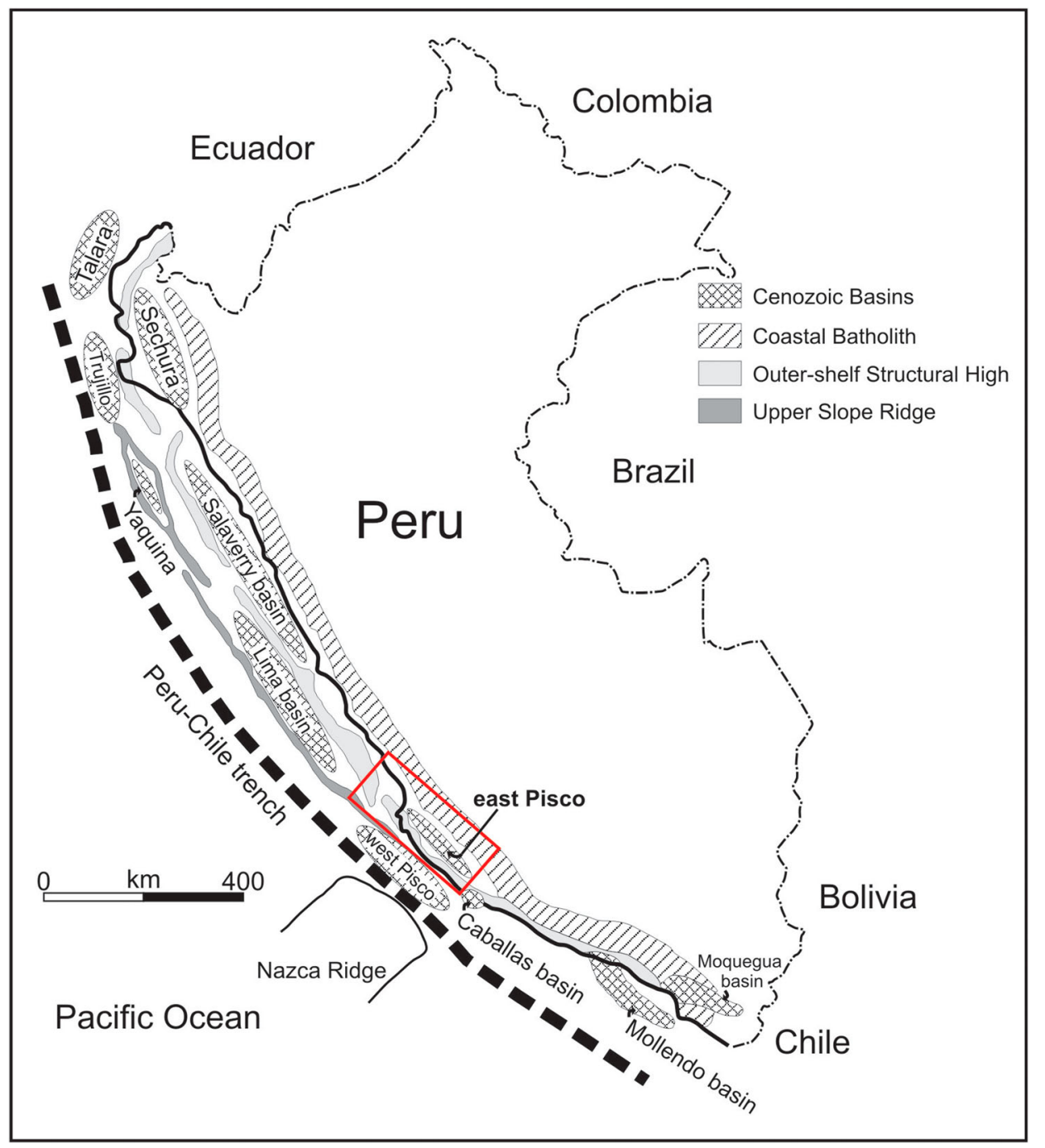

Figure 1. Sketch map of the major sedimentary basins of coastal Peru and Outer Shelf Ridge and Upper Slope Ridge, redrawn and modified from Travis, Gonzales, and Pardo (1976) and Thornburg and Kulm (1981).

outward appearance and not lithologically unique and consist of characteristic ash layers, nodule-rich horizons, and dolomite-cemented beds forming laterally persistent benches, with distinctive intervening successions above and below.

\subsubsection{Member A}

Member A occurs only in two small areas in the western and northern parts of the study area. This unit exceeds $45 \mathrm{~m}$ in thickness and is bounded above by the top of the Alcatraz marker bed, a $2 \mathrm{~m}$ thick, very fine-grained yellow sandstone bed (Figure 4 (a)). The base of Member A, due to scree and laterally continuous cover from sand dunes, is not exposed. The primary component lithologies include: (i) a basal cliff-forming package, as much as $8 \mathrm{~m}$ thick, of gray and yellow, thoroughly bioturbated, fine-grained sandstones displaying Gyrolithes burrows; (ii) a central package, $21 \mathrm{~m}$ thick, dominated by finely laminated white diatomites with sparse nodules, local concentrations of fish scales and bivalves; and (iii) an upper package, $16 \mathrm{~m}$ thick, of thoroughly bioturbated, very fine- to fine-grained yellow sandstones including two sandy coquina beds with abundant molds of bivalves and gastropods (Dosinia sp., Anadara sp., and Turritella sp.), and finely laminated white diatomites. Vertebrate fossils in this interval are fairly common and mostly consist of cetaceans and pinnipeds.

\subsubsection{Member B}

Member B is about $51 \mathrm{~m}$ thick. It represents the section from the top of the Alcatraz marker bed to the base of the Ârbol marker bed (Figure 4 (b)) and is made up of a monotonous succession of finely laminated white diatomites interbedded with sparse to locally abundant nodules, and minor volcanic ash layers and dolomitecemented beds. One of these dolomite-cemented beds forms a prominent bench and has been used as intramember marker bed (Araña marker bed). Vertebrate fossils have not been found in this interval.

\subsubsection{Member C}

This member is about $53 \mathrm{~m}$ thick and is the section from the base of the Árbol marker bed to the top of 


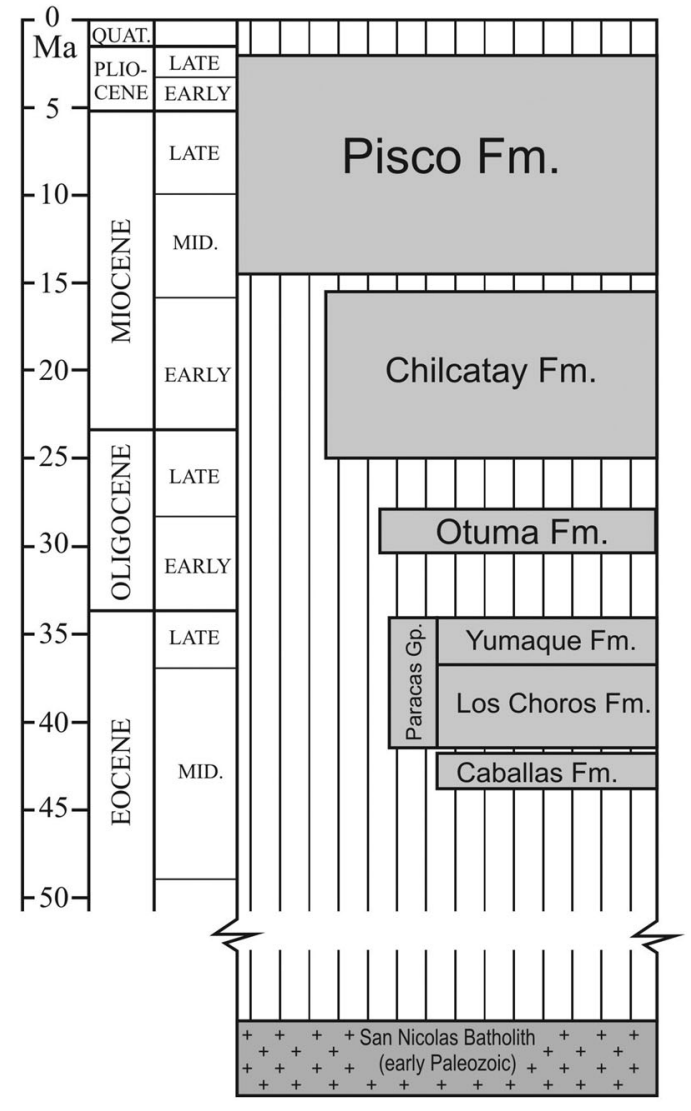

Figure 2. Schematic stratigraphic chart summarizing the main stratigraphic units of the Pisco Basin (redrawn and modified from DeVries, 1998).

the Colibrí marker bed; two dolomite-cemented horizons form laterally persistent benches (Figure 4(c)). An additional, prominent bench within member $\mathrm{C}$ is formed by a $30 \mathrm{~cm}$-thick dolomite-cemented horizon (Ballena marker bed) sandwiched between two volcanic ash layers. Member $\mathrm{C}$ consists of alternating packages of pale gray, thoroughly bioturbated, finegrained sandstones, ranging in thickness between 4 and $12 \mathrm{~m}$, and finely laminated white diatomites of varying thickness. Vertebrate fossils are rare.

\subsubsection{Member $D$}

Member $\mathrm{D}$ is about $46 \mathrm{~m}$ thick and is the section interposed between the top of the Colibrì marker bed to the base of the Estrella marker bed (Figure 4(d)). This member is made up of a monotonous succession of finely laminated white diatomites interbedded with sparse nodules, and minor volcanic ash layers, and dolomite-cemented beds. One of these volcanic ash layers is dark gray and shows soft-sediment deformation characterized by convolute bedding and syndepositional folds that thicken and thin irregularly. These peculiar features make it particularly useful for intramember lateral correlations (Condor marker bed). An additional marker bed is represented by a dolomite-cemented bed (Espiral marker bed) across which a clear change in weathering profile, with cliffforming diatomites below and largely recessive, slopeforming diatomites above, is recorded. Vertebrate fossils are fairly common.

\subsubsection{Member $E$}

This member, embracing the section comprised between the base of the Estrella marker bed and the base of the Flor marker bed, is $22 \mathrm{~m}$ thick and consists

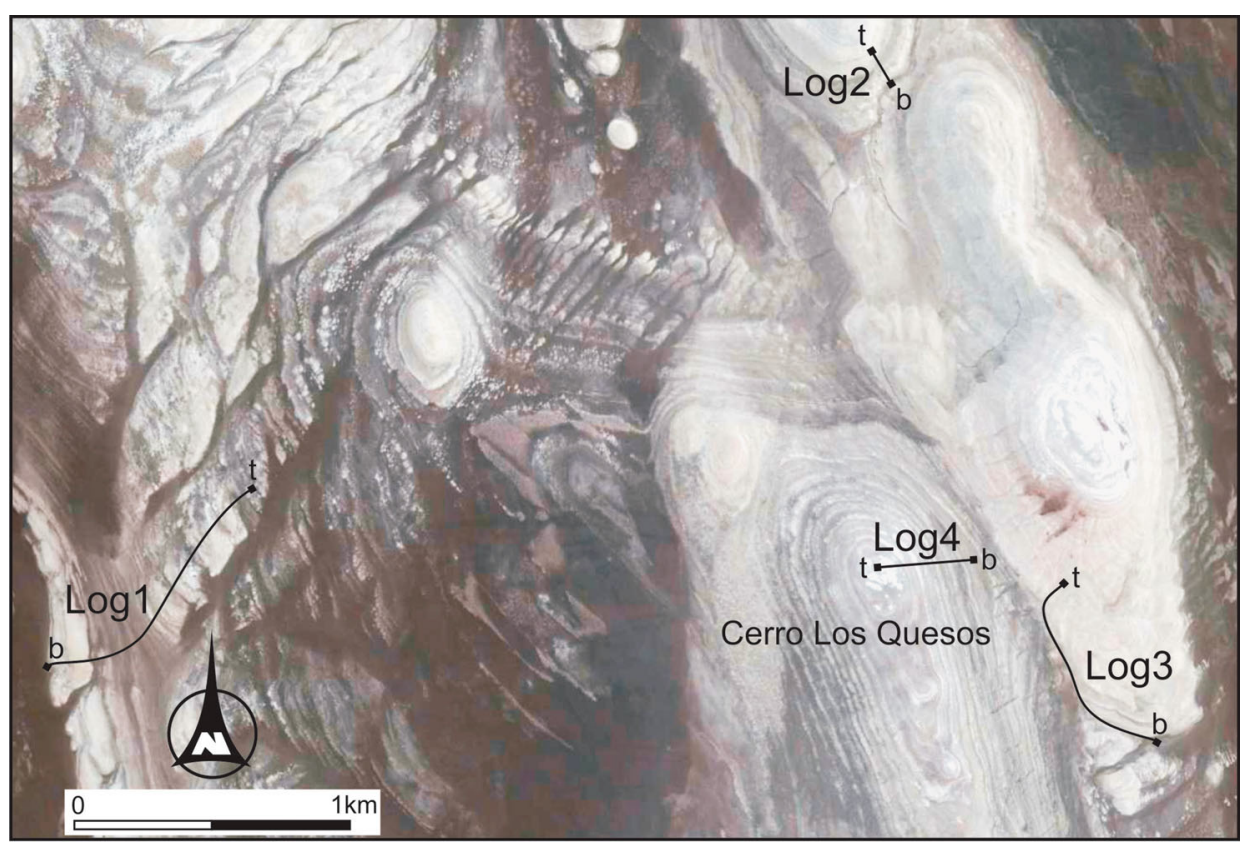

Figure 3. Google Earth image (Image $\odot 2015$ Digital Globe) showing the locations of the four sections measured at Cerro Los Quesos ( $b=$ base and $t=$ top). Log 1 is from the stratigraphically lowest exposure of Member A to the base of the Árbol marker bed; Log 2 is from the base of the Árbol marker bed to the Condor marker bed; Log 3 is from the top of the Colibrì marker bed to the Manos marker bed; Log 4 is from the Manos marker bed to the top of the Cerro Los Quesos hill. 

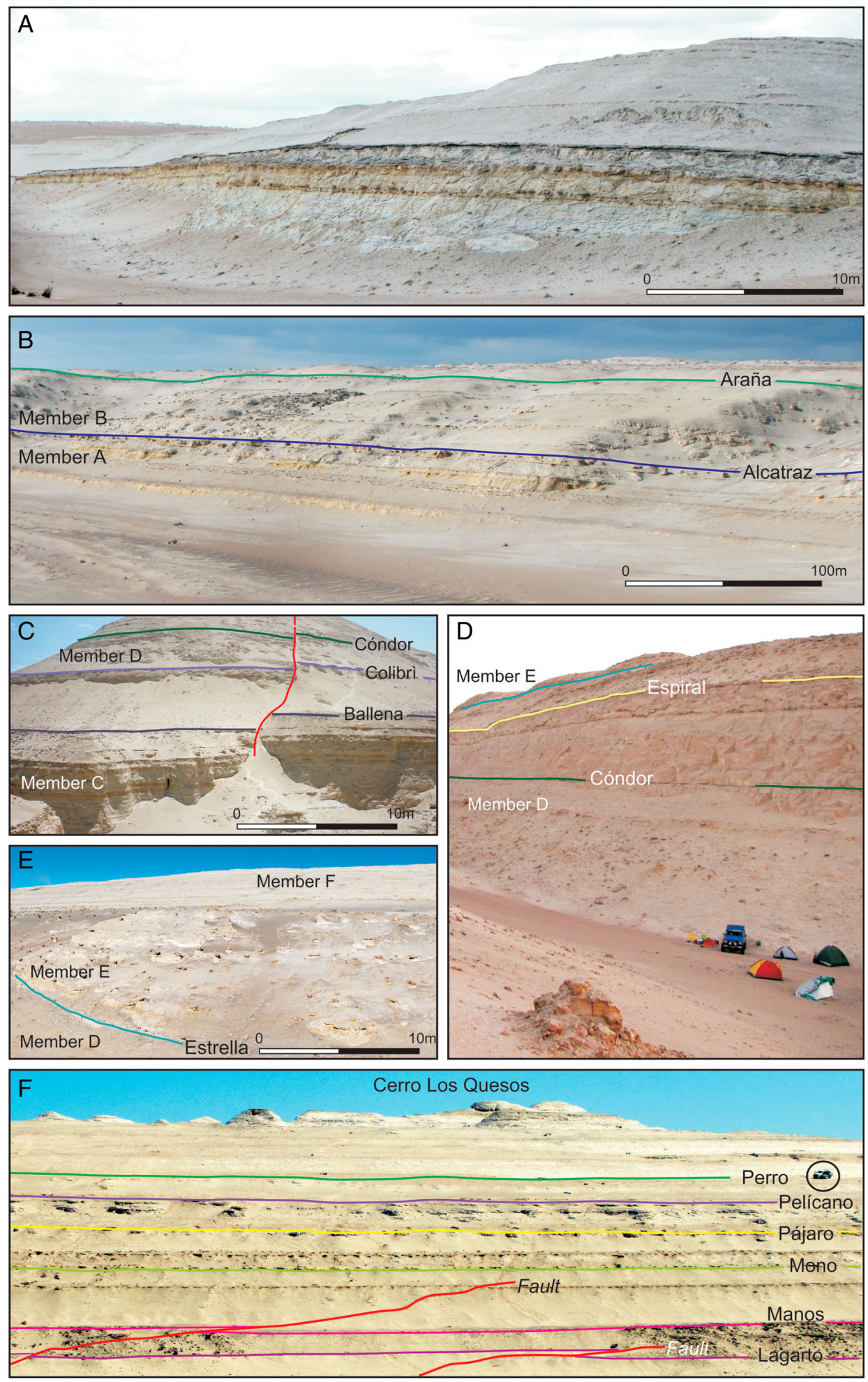

Figure 4. Compilation of photographs showing typical features of members A-F of the Pisco Formation near Cerro Los Quesos. (a) Overview of the lowest portion of Member $A$ in the measured stratigraphic column showing the lower sandstones (ss) and middle laminated diatomites (Id) $\left(14^{\circ} 29^{\prime} 56.7^{\prime \prime} \mathrm{S}-75^{\circ} 43^{\prime} 05.8^{\prime \prime} \mathrm{W}\right)$; (b) general view of the yellowish sandstones in the upper portion of Member $A$ and the overlying whitish, laminated diatomites in the lower portion of Member B $\left(14^{\circ} 31^{\prime} 33.6^{\prime \prime} \mathrm{S}-75^{\circ} 44^{\prime} 13.2^{\prime \prime} \mathrm{W}\right)$; (c) view of the upper part of Member $C$ showing marker beds $\left(14^{\circ} 29^{\prime} 56^{\prime \prime} \mathrm{S}-75^{\circ} 43^{\prime} 06^{\prime \prime} \mathrm{W}\right)$; (d) large exposure showing sediments and marker

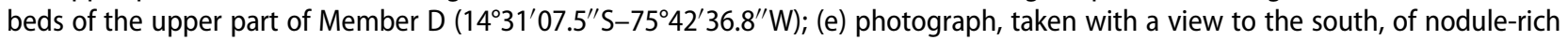
Member E (14 $\left.31^{\prime} 06^{\prime \prime} \mathrm{S}-75^{\circ} 42^{\prime} 46^{\prime \prime} \mathrm{W}\right)$; (f) eastward view of the Cerro Los Quesos outcrop showing the key stratigraphic marker beds through Member F (14 $\left.30^{\prime} 50.5^{\prime \prime} \mathrm{S}-75^{\circ} 43^{\prime} 01.3^{\prime \prime} \mathrm{W}\right)$. Encircled car for scale.

of finely laminated white diatomites characterized by the occurrence of a high density of large, elongated or discoidal nodules that are roughly parallel in orientation to each other (Figure 4(e)). Vertebrate fossils, commonly preserved within hard carbonate concretions, occasionally occur. 


\subsubsection{Member $F$}

This is $75 \mathrm{~m}$-thick and is composed mainly of a monotonous succession of finely laminated white diatomites interbedded with sparse nodules, volcanic ash-fall deposits, and dolomite-cemented beds (Figure 4(f)). The base of Member $\mathrm{F}$ is defined by a characteristic stratigraphic marker (Flor marker bed) including two dolomite-cemented beds sandwiching an ash layer. Some of the dolomite-cemented beds in the succession tend to stand out from the most easily eroded diatomites around them, forming prominent benches across their entire lateral extent and serving as stratigraphic key beds (Lagarto, Manos, Pájaro, Pelícano, and Perro marker beds) for high-resolution local correlations. An additional valuable marker within this member is represented by a $50 \mathrm{~cm}$-thick, whitish, biotite-bearing ash layer (Mono marker bed) showing a variety of distinctive, meso-scale soft-sediment deformation structures, such as flame-shaped tongues of ash that project upward into the overlying diatomites, load casts resulting from the vertical sinking of the denser upper diatomites into the less dense underlying ash, and convolutions.

Vertebrate fossils are extremely common and this member preserves the bulk of the fossils documented at Cerro Los Quesos. The elevated number of closely spaced marked beds recognized within this unit provided a very high stratigraphic resolution and allowed the precise stratigraphic placement of the vertebrate fossils it contains (Bianucci, Di Celma, Collareta, et al., in press).

\subsection{Structural analysis}

Even though the stratigraphy of the Pisco Formation at Cerro Los Quesos is relatively simple and depicts a 'layer-cake' arrangement of beds, intense faulting poses a significant challenge to reconstructing a detailed stratigraphic record and attempts to compare laterally separated outcrops through precise alongstrike correlations may be especially difficult. The majority of faults exposed in the study area are northwest-trending, high-angle normal faults that dip steeply both to the southwest and the northeast and show a minor right-lateral component of motion (rake angles of striations are $70^{\circ}-90^{\circ}$ ). Their traces are up to outcrop height (up to $\sim 140 \mathrm{~m}$ ) and some hundreds of meters long, but some faults are longer (up to over $2 \mathrm{~km}$ ). The amount of displacement along the faults is usually less than $10 \mathrm{~m}$, rarely up to $30 \mathrm{~m}$, and also varies along strike, occasionally tipping out into a fracture with no displacement (Rustichelli, Di Celma, Tondi, \& Bianucci, in press). Most of the fault zones are marked by an abundance of gypsumfilled veins.

\section{Chronostratigraphic framework}

A micropaleontological analysis of the diatomite samples and radiometric dating of interbedded ash layers provide the basis for an integrated biostratigraphic and tephrostratigraphic framework for the portion of the Pisco Formation exposed in the study area.

\subsection{Biostratigraphy}

Diatom abundance within Cerro Los Quesos sediments agrees with the lithologic subdivision into members. The sandy members (A and C) are those where diatoms are less present (some samples of the Member $\mathrm{C}$ are completely barren of diatoms), while diatoms increase in Member $\mathrm{F}$, where they represent from 20 to $>60 \%$ in volume of the bulk sediment. Although diatoms are abundant, marker species are diluted with long-ranging species (Chaetoceros resting spores, large Coscinodiscus, Thalassionema nitzschioides, etc.) and, therefore, they are difficult to find. Some of these long-ranging species point to a coastal depositional environment. Moreover, because marker species are generally oceanic, their presence is probably related to open ocean waters sporadically entering into the basin and their distribution within the sedimentary succession may not be representative of their absolute range (i.e. their appearance/disappearance in the Cerro Los Quesos sedimentary succession may be delayed/anticipated in respect to their actual First Occurrences -FO- /Last Occurrences -LO- ).

Although species first and last occurrences cannot be univocally pinpointed, the interval from 213.5 to $237.3 \mathrm{~m}$ above the base of the section (end of Member $\mathrm{E}$ and base of Member F) is characterized by the cooccurrence of two marker species: Nitzschia porteri and Nitzschia miocenica. The first has its LO at 7.1 $\mathrm{Ma}$ (ages for tropical planktonic diatoms in the equatorial Pacific, Barron, 2003), the latter has its FO at $7.35 \mathrm{Ma}$ (low-latitude diatom zonation of Barron, 1985), therefore constraining this part of the section between 7.35 and $7.1 \mathrm{Ma}$, and corresponding to the base of the Nitzschia miocenica zone (low-latitude diatom zonation of Barron, 1985).

Other marker species present in the Cerro Los Quesos stratigraphic section are Thalassiosira antiqua, which is known to range from 8.5 to $1.6 \mathrm{Ma}$ (Barron, 2003, ages for middle-to-high-latitude North Pacific) but is present only in few sample of Member B, Nitzschia reinholdii, Koizumia tatsunokuchiensis, and Denticulopsis hustedtii.

Finally, it is important to highlight the presence of plicated Thalassiosira individuals throughout the studied section. Preliminary SEM investigations have revealed their affinities with Thalassiosira flexuosa (Brun) (Akiba \& Yanagisawa, 1986), as described by 
Tanimura (1996). Although the range of this species in DSDP site 173 is significantly older (LO ca. $8.85 \mathrm{Ma}$, Tanimura, 1996) than the Cerro Los Quesos succession and cannot be used for age constriction, the presence of plicated Thalassiosira may help in future correlations with different sections of the Pisco Formation.

\subsection{Tephrostratigraphy}

Within the measured section, the Pisco Formation embodies at least 59 measurable volcanic ash layers, varying in thickness from 5 to $50 \mathrm{~cm}$, as well as several more ash layers too thin to be shown on the stratigraphic section with the established minimum bed thickness. Not all the ash layers are preserved as primary deposits, with some resulting from reworking and admixture of siliciclastic detritus. The primary ash layers are characterized by distinctive lithology, stratigraphic position, geochemical (glass composition, ranging from 62 to $77 \mathrm{wt} \%$ of $\mathrm{SiO}_{2}$ and from 4 to $6 \mathrm{wt} \%$ of $\mathrm{K}_{2} \mathrm{O}$, therefore from andesitic to rhyolitic) and mineralogical fingerprint (relative proportion of minerals and/or mineral chemistry) and provide mappable isochronous surfaces across the Pisco Formation.

The major age control on the studied succession is provided by ${ }^{40} \mathrm{Ar} /{ }^{39} \mathrm{Ar}$ dating of biotite from three of the measurable ash layers. These are rhyolitic ashes, mainly consisting of vesiculated clear glassy clasts, with rounded or stretched vesicles, transparent to whitish in color, bearing feldspars besides biotite as juvenile crystals. The resulting dates provide a consistent framework, further supporting the late Miocene age provided by the micropaleontological analysis. The stratigraphically lowest of the three dated ash layers, resting directly on top of the Ballena marker bed, was described and sampled at $14^{\circ} 29^{\prime} 56^{\prime \prime} \mathrm{S}-75^{\circ} 43^{\prime} 06.8^{\prime \prime} \mathrm{W}$ and gave an age of $7.55 \pm 0.05 \mathrm{Ma}$ (all uncertainties are given at the $95 \%$ confidence level). The Mono marker bed, about $110 \mathrm{~m}$ above the Ballena marker bed, was described and sampled at $14^{\circ} 30^{\prime} 50.5^{\prime \prime} \mathrm{S}-75^{\circ}$ $43^{\prime} 01.3^{\prime \prime} \mathrm{W}$ and gave an age of $6.93 \pm 0.09 \mathrm{Ma}$. The stratigraphically highest tephra is exposed in the uppermost part of the Cerro Los Quesos section and was described and sampled at $14^{\circ} 30^{\prime} 50.65^{\prime \prime} \mathrm{S}-75^{\circ}$ $43^{\prime} 07.01^{\prime \prime} \mathrm{W}$. Dating of biotite gave a lower limit for the age of the ash deposit, $t \geq 6.71 \pm 0.02 \mathrm{Ma}$.

\section{Conclusions}

The $290 \mathrm{~m}$-thick sedimentary section of the Pisco Formation exposed at Cerro Los Quesos has not been previously described in detail, and no stratigraphic framework exists for this area.

The investigated portion of the Pisco Formation includes sandstone, siltstone, and tuffaceous and diatomaceous mudstones forming an extensionally faulted, eastward-dipping monocline that has been informally subdivided into six mappable members designated (youngest to oldest) A through F. Fifteen stratigraphic markers have been mapped throughout the Cerro Los Quesos section and provided the key for unlocking the detailed stratigraphy and the geology of the area.

Age constraints resulting from a combination of diatom biostratigraphy and ${ }^{40} \mathrm{Ar} /{ }^{39} \mathrm{Ar}$ isotopic dating of three interbedded volcanic ash layers led to a refined chronostratigraphic framework and suggests a late Miocene age for the studied succession.

\section{Software}

The geological map and associated geological sections were compiled by scanning hand drafts as black and white TIF files, and then digitizing the linework using the Corel Draw X3 graphics package. By using the GIS Data processing application Global Mapper 12, contour lines for the 1:10,000 scale topographic base map were generated from digital elevation models (DEMs) based on the Shuttle Radar Topography Mission 26 (SRTM) as released by the United States Geological Survey (SRTM3 USGS version 2.1).

\section{Acknowledgements}

The logistics of fieldwork were greatly assisted by Mario Urbina (Museo de Historia Natural, Universidad Nacional Mayor de San Marcos, Lima). Journal reviewers Gianluca Cornamusini, Mauro Aldinucci, Jenny Bernhard and Associate Editor Randall Orndorff are gratefully acknowledged for their thoughtful contribution and helpful criticism that sharpened the focus of this study. Last, but not least, C.D.C. would like to thank his wife Desy and his two lovely children Marco and Sveva for their endless patience during the long periods he spent in the field.

\section{Disclosure statement}

No potential conflict of interest was reported by the authors.

\section{Funding}

This study was supported by grants from the Italian Ministry of University and Research to Bianucci (PRIN Project, 2012YJSBMK EAR-9317031), Malinverno (PRIN Project, 2012YJSBMK_002), Di Celma (PRIN Project, 2012YJSBMK_003), National Geographic Society Committee for Research Exploration to Bianucci (9410-13) and a grant by the University of Pisa (PRA_2015_0028).

\section{References}

Akiba, F., \& Yanagisawa, Y. (1986). Taxonomy, morphology and phylogeny of the Neogene diatom zonal marker species in the middle-to-high latitudes of the North Pacific. In H. Kagami, D. E. Karig, W. T. Coulbourn, et al. (Ed.), Init. Repts. DSDP, 87 (pp. 483-554). Washington, DC: U.S. Govt. Printing Office. 
Barazangi, M., \& Isacks, B. L. (1979). Subduction of the Nazca plate beneath Peru: Evidence from spatial distribution of earthquakes. Geophysical Journal of the Royal Astronomical Society, 57, 537-555.

Barron, J. A. (1985). Miocene to Holocene planktic diatoms. In H. M. Bolli, J. B. Saunders, \& K. P. Perch-Nielsen (Eds.), Plankton stratigraphy (pp. 763-809). Cambridge: Cambridge University Press.

Barron, J. A. (2003). Planktonic marine diatom record of the Past 18 M.Y.: Appearances and extinctions in the Pacific and Southern Oceans. Diatom Research, 18, 203-224.

Bianucci, C., Di Celma, C., Collareta, A., Landini, W., Post, K., Tinelli, C., ... Lambert, O. (in press). Fossil marine vertebrates of Cerro Los Quesos: Distribution of cetaceans, seals, crocodiles, seabirds, sharks, and bony fish in a late Miocene locality of the Pisco Basin, Peru. Journal of Maps. doi:10.1080/17445647.2015.1115785

Bianucci, G., Di Celma, C., Landini, W., Post, K., Tinelli, C., de Muizon, C., ... Lambert, O. (in press). Distribution of fossil marine vertebrates in Cerro Colorado, the type locality of the giant raptorial sperm whale Livyatan melvillei (Miocene, Pisco Formation Peru). Journal of Maps. doi:10.1080/1744567.2015.1048315

Bianucci, G., Lambert, O., \& Post, K. (2010). High concentration of long-snouted beaked whales (genus Messapicetus) from the Miocene of Peru. Palaeontology, 53, 1077-1098.

Brand, L., Esperante, R., Chadwick, A. V., Poma Porras, O., \& Alomía, M. (2004). Fossil whale preservation implies high diatom accumulation rate in the Miocene-Pliocene Pisco Formation of Peru. Geology, 32, 165-168.

Brand, L., Urbina, M., Chadwick, A., DeVries, J. T., \& Esperante, R. (2011). A high resolution stratigraphic framework for the remarkable fossil cetacean assemblage of the Miocene/Pliocene Pisco Formation, Peru. Journal of South American Earth Sciences, 31, 414-425.

Cahill, T., \& Isacks, B. L. (1992). Seismicity and shape of the subducted Nazca plate. Journal of Geophysical Research, 97, 17503-17529.

Cobbing, E. J. (1999). The Coastal Batholith and other aspects of Andean magmatism in Peru. In A. Castro, C. Fernandez, \& J. L. Vigneresse (Eds.), Understanding granites: Integrating new and classical techniques (Vol. 168, pp. 111-122). London: Geological Society, London, Special Publications.

Collareta, A., Landini, W., Lambert, O., Post, K., Tinelli, C., Di Celma, C., ... Bianucci, G. (2015). Piscivory in a Miocene Cetotheriidae: First record of fossilized stomach content for an extinct baleen-bearing whale. The Science of Nature-Naturwissenschaften, 102, 1-12. doi:10.1007/ s00114-015-1319-y

DeVries, T. J. (1998). Oligocene deposition and Cenozoic sequence boundaries in the Pisco Basin (Peru). Journal of South American Earth Sciences, 11, 217-231.

Di Celma, C., Malinverno, E., Gariboldi, K., Gioncada, A., Rustichelli, A., Pierantoni, P. P., ... Bianucci, G. (in press). Stratigraphic framework of the late Miocene to Pliocene Pisco Formation at Cerro Colorado. Journal of Maps. doi:10.1080/1744567.2015.1047906

Dunbar, R. B., Marty, R. C., \& Baker, P. A. (1990). Cenozoic marine sedimentation in the Sechura and Pisco basins, Peru. Palaeogeography, Palaeoclimatology, Palaeoecology, 77, 235-261.

Ehret, D. J., MacFadden, B. J., Jones, D. S., DeVries, T. J., Foster, D. A., \& Salas-Gismondi, R. (2012). Origin of the white shark Carcharodon (Lamniformes: Lamnidae) based on the upper Neogene Pisco Formation of Peru. Paleontology, 55, 1139-1153.
Esperante, R., Brand, L. R., Chadwick, A. V., \& Poma, O. (2015). Taphonomy and paleoenvironmental conditions of deposition of fossil whales in the diatomaceous sediments of the Miocene/Pliocene Pisco Formation, southern Peru - a new fossil-lagerstätte. Palaeogeography, Palaeoclimatology, Palaeoecology, 417, 337-370.

Esperante, R., Brand, L. R., Nick, K. E., Poma, O., \& Urbina, M. (2008). Exceptional occurrence of fossil baleen in shallow marine sediments of the Neogene Pisco Formation, Southern Peru. Palaeogeography, Palaeoclimatology, Palaeoecology, 257, 344-360.

Gariboldi, K., Gioncada, A., Bosio, G., Malinverno, E., Di Celma, C., Tinelli, C., ... Bianucci, G. (2015). The dolomitic nodules enclosing fossil marine vertebrates in the East Pisco Basin, Peru: Field and petrographic insights into their genesis and role in preservation. Palaeogeography, Palaeoclimatology, Palaeoecology, 438, 81-95.

Hampel, A. (2002). The migration history of the Nazca Ridge along the Peruvian active margin: A re-evaluation and some geological implications. Earth and Planetary Science Letters, 203, 665-679.

Hsu, J. T. (1992). Quaternary uplift of the Peruvian coast related to the subduction of the Nazca Ridge: 13.5 to 15.6 degrees south latitude. Quaternary International, 15-16, 87-97.

Lambert, O., Bianucci, G., \& Beatty, B. L. (2014). Bony outgrowths on the jaws of an extinct sperm whale support macroraptorial feeding in several stem physeteroids. Naturwissenschaften, 101, 517-521.

Lambert, O., Bianucci, G., \& de Muizon, C. (2008). A new stem-sperm whale (Cetacea, Odontoceti, Physeteroidea) from the latest Miocene of Peru. Comptes Rendus Palevol, 7, 361-369.

Lambert, O., Bianucci, G., \& Post, K. (2009). A new beaked whale (Odontoceti, Ziphiidae) from the Middle Miocene of Peru. Journal of Vertebrate Paleontology, 29, 910-922.

Lambert, O., Bianucci, G., \& Post, K. (2010). Tusk bearingbeaked whales from the Miocene of Peru: Sexual dimorphism in fossil ziphiids? Journal of Mammalogy, 91, 19-26.

Lambert, O., Bianucci, G., Post, K., de Muizon, C., SalasGismondi, R., Urbina, M., \& Reumer, J. (2010). The giant bite of a new raptorial sperm whale from the Miocene epoch of Peru. Nature, 466, 105-108.

Lambert, O., Collareta, A., Landini, W., Post, K., Ramassamy, B., Di Celma, C., ... Bianucci, G. (2015). No deep diving: Evidence of predation on epipelagic fish for a stem beaked whale from the late Miocene of Peru. Proceedings of the Royal Society B, 282, 20151530. doi:10.1098/rspb.2015.1530

Lambert, O., de Muizon, C., \& Bianucci, G. (2014). The most basal beaked whale Ninoziphius platyrostris Muizon, 1983: Clues on the evolutionary history of the family Ziphiidae (Cetacea: Odontoceti). Zoological Journal of the Linnean Society, 167, 569-598.

León, W., Aleman, A., Torres, V., Rosell, W., \& De La Cruz, O. (2008). Estratigrafía, Sedimentología y evolución tectónica de la cuenca Pisco Oriental. Boletín INGEMMET, 27(Serie D), pp. 144, Lima, Peru.

Macharé, J., \& Ortlieb, L. (1992). Plio-Quaternary vertical motions and the subduction of the Nazca Ridge, central coast of Peru. Tectonophysics, 205, 97-108.

Mukasa, S. B. (1986). Zircon U-Pb ages of super-units in the Coastal batholith, Peru: Implications for magmatic and tectonic processes. Geological Society of America Bulletin, 97, 241-254. 
Pilger, R. H. (1981). Plate reconstructions, aseismic ridges, and low-angle subduction beneath the Andes. Geological Society of America Bulletin, 92, 448-456.

Romero, D., Valencia, K., Alarcón, P., Peña, D., \& Ramos, V. A. (2013). The offshore basement of Perú: Evidence for different igneous and metamorphic domains in the forearc. Journal of South American Earth Sciences, 42, $47-60$.

Rustichelli, A., Di Celma, C., Tondi, E., \& Bianucci, G. (in press). Deformation within the Pisco basin sedimentary record (southern Peru): Stratabound orthogonal vein sets and their impact on fault development. Journal of South American Earth Sciences. doi:10.1016/j.jsames. 2015.11.002

Tanimura, Y. (1996). Fossil marine plicated Thalassiosira: Taxonomy and an idea of phylogeny. Diatom Research, 11, 165-202.
Thornburg, T. M., \& Kulm, L. D. (1981). Sedimentary basins of the Peru continental margin: Structure, stratigraphy, and Cenozoic tectonics from $6^{\circ} \mathrm{S}$ to $16^{\circ} \mathrm{S}$ latitude. In $\mathrm{L}$. D. Kulm, J. Dymond, E. J. Dasch, \& D. M. Hussong (Eds.), Nazca plate: Crustal formation and Andean convergence (pp. 393-422). Boulder, CO: Geological Society of America, Memoir 154.

Travis, R. B., Gonzales, G., \& Pardo, A. (1976). Hydrocarbon potential of coastal basins of Peru. American Association of Petroleum Geologists, Memoir, 25, 331-338.

Villa, I. M., Hermann, J., Müntener, O., \& Trommsdorff, V. (2000). ${ }^{40} \mathrm{Ar} /{ }^{39} \mathrm{Ar}$ dating of multiply zoned amphibole generations (Malenco, Italian Alps). Contributions to Mineralogy and Petrology, 140, 363-381.

Zúñiga-Rivero, F. J., Klein, G. D., Hay-Roe, H., \& ÁlvarezCalderon, E. (2010). The hydrocarbon potential of Peru. BPZ Exploración \& Producción S.R.L., Lima, Peru, 338 p. 